\title{
PENGARUH PENGGUNAAN TEPUNG DARAH HASIL PROSES ENZIMATIK DAN FERMENTASI DALAM PAKAN TERHADAP PERTUMBUHAN IKAN KERAPU MACAN
}

\author{
Neltje Nobertine Palinggi*), Muhammad Yamin Paada**), \\ Usman*), dan Rachmansyah*) \\ *) Balai Penelitian dan Pengembangan Budidaya Air Payau \\ Jl. Makmur Dg. Sitakka No. 129, Maros 90512, Sulawesi Selatan \\ E- mail: neltje_npt@yahoo.co.id \\ *) Balai Penelitian dan Pengembangan Budidaya Ikan Hias \\ Jl. Perikanan No. 13, Pancoran Mas, Depok 16436
}

(Naskah diterima: 13 Maret 2013; Disetujui publikasi: 9 Oktober 2013)

\begin{abstract}
ABSTRAK
Percobaan pemanfaatan tepung darah dalam formulasi pakan untuk pembesaran ikan kerapu macan telah diuji cobakan di keramba jaring apung ukuran $1 \mathrm{~m} \times 1 \mathrm{~m} \times 2 \mathrm{~m}$ menggunakan benih ikan kerapu macan ukuran 53,97 $\pm 2,92 \mathrm{~g}$ dengan padat tebar 20 ekor/keramba. Tiga tipe tepung darah yang digunakan dalam percobaan yaitu tepung darah tidak diberi perlakuan, tepung darah yang diberi perlakuan enzim protease yang diproduksi oleh mikroba Flavo cytophaga hasil seleksi dan isolasi dari saluran usus ikan kerapu macan, dan tepung darah yang difermentasi dengan menggunakan mikroba Flavo cytophaga. Jumlah tepung darah yang digunakan dalam formulasi pakan percobaan adalah $18 \%$ (mensubstitusi $24 \%$ tepung ikan). Perlakuan yang dicobakan adalah penggunaan tepung darah dalam pakan yang memiliki cara pengolahan berbeda, yaitu: (A) pakan tanpa tepung darah; (B) pakan mengandung tepung darah tanpa perlakuan; (C) pakan mengandung tepung darah hasil proses enzimatik enzim protease; dan (D) pakan mengandung tepung darah hasil fermentasi dengan mikroba Flavo cytophaga. Setiap perlakuan diulang tiga kali. Pakan tersebut dibuat dalam bentuk moist pellet berkadar protein $46 \%$ dan lemak $6 \%$ dan diberikan kepada ikan uji selama 20 minggu secara at satiation. Hasil penelitian menunjukkan ikan uji yang diberi pakan mengandung tepung darah tanpa perlakuan memberikan pertambahan bobot, laju pertumbuhan spesifik dan rasio efisiensi protein yang lebih rendah dan berbeda nyata $(P<0,05)$ dengan kontrol, sedangkan ikan yang diberi pakan tepung darah yang ditambahkan ekstrak enzim protease dan mikroba Flavo cytophaga tidak berbeda nyata $(P>0,05)$ dengan kontrol. Demikian pula nilai retensi protein, efisiensi pakan, dan sintasan ikan tidak ada perbedaan nyata $(P>0,05)$ di antara perlakuan dan kontrol.
\end{abstract}

KATA KUNCI: tepung darah, fermentasi, pakan pembesaran ikan kerapu macan

ABSTRACT: Effect of the use of blood meal results process enzymatic and fermentation as a mixture material of feed for tiger grouper fish growth. By: Neltje Nobertine Palinggi, Muhammad Yamin Paada, Usman, and Rachmansyah

The experiment for utilizing of blood meal as a feed ingradient in the diets formulation for growth-out of tiger grouper was conducted in floating net cage. Three types of blood meal used in this experiment namely; blood meal not provide treatment, blood meal given treatment enzyme protease produced by microbes Flavo cytophaga, 
result of the selection and isolation from intestinal track of tiger grouper, and blood meal fermented by using microbes Flavo cytophaga. The amount of blood meal used in the experiment diets is $18 \%$ (substitution $24 \%$ of fish meal). Twelve net cages of $1 \mathrm{~m} \times 1 \mathrm{~m} \times 2 \mathrm{~m}$ in size, each containing 20 tiger grouper juveniles with average initial body weight of $53.97+2.92 \mathrm{~g}$, were set up randomly in seawater. The treatments were four experimental diets consist of, diet $(A)$ without blood meal, diet $(B)$ with blood meal, diet (C) with blood meal given treatment enzyme protease, and diet (D) with blood meal fermented by microbes Flavo cytophaga. Each treatment was repeated three times. The test diets were formulated in moist pellet and contained $46 \%$ protein and $6 \%$ lipid. The test fish fed two time daily at satiation for 20 weeks. The results shown that the fish fed the diet containing unfermented-blood meal. The results showed that the test fish were fed blood meal without treatment gives had lower and significantly different $(\mathrm{P}<0.05)$ weight gain, specific growth rate, and protein efficiency ratio compared to the fish fed the control diet, while the fish fed the diet containing blood meal meal with the addition of crude extract of protease or blood meal with the addition of Flavo cytophaga bacteria had not significantly different $(P>0.05)$ weight gain, specific growth rate, and protein efficieny ratio compared to the fish fed the control diet. Protein retention and feed efficiency had not significant different $(P>0.05)$ among fish fed the all treatments and control diet.

\section{KEYWORDS: blood meal, fermentation, grow- out tiger grouper diet}

\section{PENDAHULUAN}

Ikan kerapu macan (Epinephelus fuscoguttatus) merupakan salah satu komoditas ekspor Indonesia dari sektor perikanan yang saat ini pembesarannya pada keramba jaring apung di laut sedang berkembang. Aktivitas budidaya ini tentunya membutuhkan pakan buatan yang memenuhi persyaratan nutrisi, ekologi, dan ekonomi. Kontribusi pakan dalam kegiatan budidaya masih sekitar $60 \%$ dari total biaya produksi, sehingga memiliki peran strategis bagi keberhasilan usaha.

Ikan kerapu macan sebagai ikan karnivora cenderung membutuhkan pakan dengan kandungan protein yang tinggi yakni antara 45\% 50\%(Laining et al., 2003a; Laining et al., 2003b; Kabangnga et al., 2004) sehingga perlu memperhatikan manajemen pakan agar dapat mengefisienkan pakan dan mengoptimalkan pertumbuhan ikan. Salah satu cara yang dapat dilakukan adalah dengan memanfaatkan enzim protease yang dihasilkan oleh usus ikan tersebut. Penelitian Aslamyah (2006) mencatat bahwa pemberian enzim protease dari mikroba saluran pencernaan pada pakan (predesgition) benih ikan bandeng sangat nyata meningkatkan retensi protein dan pertumbuhan yang mengindikasikan peningkatan ketersediaan protein pakan.

Enzim protease adalah enzim yang berperan dalam proses pencernaan protein dalam tubuh. Dalam sistem pencernaan ikan, protein dari pakan tidak langsung diserap tetapi didegradasi terlebih dahulu oleh enzim protease menjadi asam amino kemudian diserap. Proses degradasi protein ini terjadi di lambung dan usus, sementara penyerapan makanan terjadi di usus (Fujaya, 2004). Selain untuk degradasi protein nutrien, protease juga diperlukan dalam sejumlah reaksi biokimia tubuh seperti mekanisme patogenisitas, proses koagulasi darah, proses sporulasi, diferensiasi, sejumlah proses pasca translasi protein, dan mekanisme ekspresi protein ekstra seluler (Rao et al., 1998).

Umumnya beberapa bahan baku lokal untuk pakan ikan masih diproses secara tradisional sehingga masih mengandung beberapa zat antinutrisi dengan kadar yang beragam serta ikatan kimia yang masih kompleks. Agar bahan baku pakan itu mudah dimanfaatkan dengan baik oleh ikan, maka perlu diupayakan peningkatan ketersediaan bahan baku tersebut antara lain dengan metode fermentasi dan menambahkan crude enzym.

Bahan baku yang dapat digunakan sebagai bahan substitusi tepung ikan antara lain adalah tepung darah. Tepung darah diperoleh dari limbah pemotongan hewan mengandung protein 82,04\% 87,8\%bobot kering (Palinggi, 2008). Walaupun tepung darah mengandung kadar protein tinggi, namun penggunaannya dalam pakan ikan terbatas mengingat kemampuan ikan dalam mencerna tepung darah 
terbatas (Palinggi, 2008). Berdasarkan hal tersebut maka perlu dilakukan usaha untuk mencari metode yang dapat membantu meningkatkan kualitas tepung darah. Salah satu cara yang pernah dilakukan adalah dengan menambahkan asam formiat 3\%pada tepung darah. Penggunaaan asam formiat 3\% pada tepung darah dapat meningkatkan kandungan total asam amino dari 31,88\%menjadi 55,01\% (Rachmansyah et al., 1999).

Selain cara tersebut di atas, peningkatan kualitas tepung darah dapat juga dilakukan dengan cara fermentasi menggunakan mikroorganisme. Mikroorganisme dapat membantu proses pencernaan pakan di dalam saluran pencernaan ikan karena mikroorganisme mengandung sejumlah enzim untuk menghidrolisis protein, lemak, dan karbohidrat. Jenis enzim yang dapat dihasilkan oleh mikroorganisme antara lain amilase, glukoamilase, protease, laktase, katalase, glukosa oksidase, lipase, selulase, hemiselulase, dan pektinase (Suhartono, 1989). Berdasarkan hal tersebut maka perlu dilakukan kajian perbaikan mutu tepung darah sebagai salah satu bahan substitusi tepung ikan melalui penggunaan mikroorganisme. Penelitian ini bertujuan untuk mengetahui pengaruh penggunaan tepung darah yang telah dihidrolisis dengan enzim protease, tepung darah yang difermentasi dengan mikroba saluran pencernaan (Flavo cytophaga) dalam formulasi pakan terhadap pertumbuhan ikan kerapu macan. Juga dievaluasi kualitas pakan yang menggunakan tepung darah dalam berbagai perlakuan dan pakan yang hanya menggunakan sumber protein tepung ikan.

\section{BAHAN DAN METODE}

\section{Pakan Uji}

Darah yang digunakan diperoleh dari tempat pemotongan sapi. Darah tersebut dikukus kemudian digiling lalu dikeringkan. Darah yang sudah kering kemudian digiling kembali hingga menjadi tepung yang selanjutnya diproses sesuai perlakuan. Perlakuan yang dicobakan adalah: (A) pakan tanpa tepung darah; (B) pakan mengandung tepung darah tanpa proses perlakuan; (C) pakan mengandung tepung darah hasil proses enzimatik enzim protease; dan (D) pakan mengandung tepung darah hasil fermentasi dengan menggunakan mikroba Flavo cytophaga yang diisolasi dari saluran pencernaan ikan kerapu macan.
Produksi ekstrak kasar enzim protease dilakukan di Laboratorium Nutrisi Balai Riset Perikanan Budidaya Air Payau (BRPBAP), Maros. Mikroba Flavo cytophaga diperoleh dari usus ikan kerapu macan yang dipelihara dalam keramba jaring apung (Yamin et al., 2008). Produksi ekstrak kasar enzim ini dilakukan dalam empat tahap (berdasarkan metode yang dikembangkan oleh Yamin et al. (2005), yaitu pemurnian (screening), pembuatan inokulum, produksi enzim kasar, dan pemisahan enzim kasar dari sel bakteri. Pemurnian kembali bakteri stok dilakukan dengan cara mengambil 1 ose dari media stok dan ditebar pada cawan petri yang berisi modifikasi media luria agar/ LA (yeast extract $0,5 \%$ tripton $1 \% \mathrm{Na} \mathrm{Cl} 1 \%$ skim milk $1,5 \%$ dan bacto agar $1,5 \%$ pada suhu kamar selama satu malam. Koloni bakteri yang menghasilkan zone bening (hallo) dipindahkan ke cawan petri lainnya dan ditumbuhkan dengan cara yang sama untuk dijadikan stok bakteri. Pembuatan inokulum dilakukan dengan cara mengambil 1 ose dari bakteri stok dan dimasukkan dalam tabung erlenmeyer berisi media luria bertani/ LB (yeast extract $0,5 \%$ tripton $1 \% \mathrm{NaCl} 1 \%$ dan dikocok selama satu malam pada suhu ruang. Perubahan warna media menjadi keruh menandakan bakteri yang dikultur telah tumbuh. Produksi enzim protease dilakukan dengan memasukkan sebanyak $10 \%$ bakteri inokulum pada media skim milk (yeast extract $0,5 \%$ tripton $1 \% \mathrm{Na}$ $\mathrm{Cl} 1 \%$ dan skim milk $1,5 \%$. Selanjutnya dikocok dengan kecepatan 220 rpm selama 72 jam (tiga hari) pada suhu ruang. Pemisahan enzim protease dari sel bakteri dilakukan dengan cara sentrifugasi pada kecepatan $6.000 \mathrm{rpm}$ selama sepuluh menit pada suhu $4^{\circ} \mathrm{C}$. Cairan supernatan yang berisi ekstrak enzim protease dipisahkan dan ditampung pada tabung erlenmeyer steril sedangkan endapan yang berisi bakteri ditampung dan dimusnahkan. Selanjutnya ekstrak enzim protease disimpan pada suhu $4^{\circ} \mathrm{C}$ sampai saat digunakan (Yamin et al., 2005). Penggunaan ekstrak enzim protease ini dalam tepung darah dilakukan dengan mengambil $1 \mathrm{~kg}$ tepung darah yang sudah disteril (dalam autoclave) dan dimasukkan ke dalam baskom kemudian ditambah $400 \mathrm{~mL}$ ekstrak enzim protease dan 1,5 L aquabidest lalu ditutup dengan plastik. Tepung darah ini didiamkan selama semalam pada suhu kamar setelah itu, dikeringkan dan selanjutnya ditambahkan bahan pakan lainnya (Tabel 1).

Tepung darah yang ditambahkan mikroba Flavo cytophaga dilakukan dengan cara 
menambahkan $10 \%$ inokulum bakteri pada media tepung darah (yeast extract $0,5 \%$ tripton $1 \% \mathrm{Na} \mathrm{Cl} 1 \%$ dan tepung darah $10 \%$ lalu dikocok pada kecepatan $220 \mathrm{rpm}$ pada suhu ruang selama 72 jam (tiga hari) (Yamin et al., 2005). Tepung darah yang telah diolah selanjutnya di-autoclave dan dikeringkan. Bahan yang sudah kering ini ditambahkan dengan bahan pakan lainnya (Tabel 1).

\section{Hewan Uji dan Kondisi Percobaan}

Penelitian ini dilakukan dalam keramba jaring apung, ukuran $1 \mathrm{~m} \times 1 \mathrm{~m} \times 2 \mathrm{~m}$, meng- gunakan benih ikan kerapu macan ukuran $53,97 \pm 2,92 \mathrm{~g}$ dengan padat tebar 20 ekor/ keramba. Pakan diberikan dua kali sehari secara satiasi dalam bentuk moist pellet dengan kadar protein $46 \%$ dan lemak $6 \%$ (Tabel 1). Ukuran diameter pakan disesuaikan dengan bukaan mulut ikan. Percobaan ini disusun dalam rancangan acak lengkap dan masing-masing perlakuan terdiri atas tiga ulangan. Setiap empat minggu dilakukan sampling untuk mengetahui perkembangan pertumbuhan ikan dan mortalitas ikan.

Tabel 1. Komposisi dan analisis proksimat pakan kontrol (A), tepung darah tanpa perlakuan (B), tepung darah yang ditambahkan enzim protease (C), dan tepung darah yang ditambahkan mikroba Flavo cytophaga (D) (\%bobot kering)

Table 1. Composition and proximate analysis of the control diet (A), blood meal without treatment (B), blood meal with protease enzyme (C) and blood meal fermented with microbes Flavo cytophaga (D) (\%dry weight)

\begin{tabular}{|c|c|c|c|c|c|}
\hline \multirow{2}{*}{\multicolumn{2}{|c|}{$\begin{array}{c}\text { Bahan } \\
\text { Ingredients }\end{array}$}} & \multicolumn{4}{|c|}{ Pakan uji (Test diets) } \\
\hline & & $\mathbf{A}$ & B & C & D \\
\hline & Tepung ikan (Fish meal) & 49 & 25 & 25 & 25 \\
\hline & Ikan rucah (Trash fish ${ }^{1)}$ ) & 50 & 50 & 50 & 50 \\
\hline & Tepung darah (Blood meal) & - & 18 & 18 & 18 \\
\hline & Dedak halus (Rice brand) & 9 & 10 & 10 & 10 \\
\hline & Tepung terigu (Wheat flour) & 8.5 & 9.5 & 9.5 & 9.5 \\
\hline & Tepung kedelai (Soybean meal) & 7 & 8 & 8 & 8 \\
\hline & Tepung kepala udang (Shrimp head meal) & 8 & 8 & 8 & 8 \\
\hline & Minyak ikan lemuru (Sardine oil) & 2 & 4 & 4 & 4 \\
\hline & Minyak kedelai (Soybean oil) & 1 & 2 & 2 & 2 \\
\hline & Campuran mineral (Mineral mix ${ }^{2)}$ ) & 1 & 1 & 1 & 1 \\
\hline & Campuran vitamin (Vitamin mix ${ }^{3)}$ ) & 2 & 2 & 2 & 2 \\
\hline \multicolumn{6}{|c|}{ Analisis proksimat (Proximate analysis) } \\
\hline & Protein kasar (Crude protein ) & 46.59 & 46.81 & 47.05 & 46.51 \\
\hline & Lemak kasar (Crude lipid) & 6.25 & 6.18 & 6.28 & 6.18 \\
\hline & Serat kasar (Crude fiber) & 3.44 & 3.11 & 2.57 & 3.50 \\
\hline & Abu (Ash) & 17.49 & 17.42 & 17.64 & 17.38 \\
\hline & BETN (NFE) & 26.33 & 26.48 & 26.46 & 26.43 \\
\hline & Kadar air (Moisture) & 3.00 & 2.73 & 3.05 & 3.13 \\
\hline \multicolumn{6}{|c|}{$50 \mathrm{~g}$ ikan rucah setara dengan $12,5 \mathrm{~g}$ tepung ikan } \\
\hline & \multicolumn{5}{|c|}{$\begin{array}{l}\text { Mineral mix (g/ } \mathrm{kg} \text { of mix): kalsium 32,5\% fosfor } 107 \% \text { Fe } 6 \mathrm{~g} \text {; Mn } 4 \mathrm{~g} \text {; iodin } 0,075 \mathrm{~g} \text {; Cu 0,3 g; Zn } \\
3,75 \mathrm{~g} \text { : vitamin B12 0,5 mq; vitamin D3 } 50.000 \mathrm{IU}\end{array}$} \\
\hline & \multicolumn{5}{|c|}{$\begin{array}{l}\text { Vitamin mix (g/ kg of mix): vitamin A } 60.000 .000 \text { IU2; vitamin D3 } 12.000 .000 \text { IU; vitamin E } \\
120.000 \mathrm{mg} \text {; vitamin K3 } 12.500 \mathrm{mg} \text {; vitamin B1 } 10.000 \mathrm{mg} \text {; vitamin B2 } 25.000 \mathrm{mg} \text {; vitamin B6 } \\
10.000 \mathrm{mg} \text {; vitamin B12 } 100 \mathrm{mg} \text {; vitamin C } 150.000 \mathrm{mg} \text {; folic acid } 5.000 \mathrm{mg} \text {; nicotinic acid } 60.000 \\
\text { mg1; D- pantothenic acid } 50.000 \mathrm{mg} \text {; Dl- methionine } 50.000 \mathrm{mg} \text {; biotin } 125 \mathrm{mg}\end{array}$} \\
\hline
\end{tabular}


Respon Pertumbuhan dan Pemanfaatan Pakan Uji

Peubah yang diamati meliputi pertambahan bobot badan ikan (\% setelah pemeliharaan selama 20 minggu dan laju pertumbuhan spesifik (SGR) ikan yang dihitung berdasarkan rumus berikut (Schulz et al., 2005):

$$
\text { SGR }\left(\% \text { day }^{-1}\right)=\frac{\ln W e-\ln W s}{d} \times 100 \%
$$

di mana:

We = bobot ikan pada akhir percobaan (g); Ws = bobot ikan pada awal percobaan (g); dan $\mathrm{d}=$ periode pemeliharaan (hari)

Efisiensi pakan $(\mathrm{FE})=$ Pertambahan bobot ikan (g bobot basah) / Jumlah konsumsi pakan (g bobot kering) (Takeuchi, 1988)

Rasio efisiensi protein (PER) = Pertambahan bobot ikan (g bobot basah)/ Jumlah konsumsi protein (g bobot kering) (Takeuchi, 1988)

Retensi protein $(\%)=100 \times$ Pertambahan protein ikan (g)/ Jumlah konsumsi protein (g)\}(Takeuchi, 1988)

Sintasan $(\%)=\{u m l a h$ ikan akhir $/$ Jumlah ikan awal $\} \times 100 \%$

Pada akhir penelitian juga dilakukan pengamatan kecernaan pakan. Analisis kecernaan pakan dilakukan dengan metode tidak langsung menggunakan kromium oksida $\left(\mathrm{Cr}_{2} \mathrm{O}_{3}\right)$ sebanyak $1 \%$ yang ditambahkan dalam pakan uji (Takeuchi, 1988). Pakan perlakuan berkrom diberikan pada ikan uji selama tujuh hari secara satiasi dalam keramba. Pengumpulan feses dilakukan pada hari ke- 8. Setelah satu jam selesai makan, ikan uji dipindahkan secara hati- hati ke dalam bak fiber berbentuk kerucut yang dilengkapi dengan aerasi dan air mengalir untuk mengumpulkan fesesnya. Feses dikumpulkan setiap tiga jam, untuk mencegah terjadi leaching nutrien pada feses. Feses yang terkumpul dikompositkan untuk setiap unit percobaan. Setelah dilakukan pengumpulan feses, ikan uji dipindahkan kembali ke dalam keramba, kemudian ikan diberi pakan perlakuan untuk pengumpulan feses pada hari berikutnya. Pengumpulan feses berlangsung selama 7- 10 hari bergantung pada jumlah feses yang terkumpul untuk kebutuhan analisis kimia. Feses yang sudah terkumpul dikeringkan dalam oven pada suhu $60^{\circ} \mathrm{C}$ kemudian didinginkan dalam desicator untuk siap dianalisis. Koefisien ke- cernaan bahan kering, protein, dan lemak dari pakan uji dihitung dengan rumus:

Koefisien kecernaan bahan kering $\left(A D_{D M}\right)$ :

$$
A D_{D M}(\%)=\left[1-\left[\frac{M_{D}}{M_{F}}\right]\right] \times 100 \%
$$

di mana:

$M_{D}$ dan $M_{F}$ berturut-turut adalah konsentrasi indikator $\mathrm{Cr}_{2} \mathrm{O}_{3}$ dalam pakan dan feses

Koefisien kecernaan nutrien (protein, lemak) (AD):

$$
A D(\%)=\left[1-\left[\frac{M_{D} \times A_{F}}{M_{F} \times A_{D}}\right]\right] \times 100 \%
$$

di mana:

$A_{D}$ and $A_{F}$ adalah konsentrasi nutrien (bobot kering) dalam pakan dan feses

\section{Analisis Kimia dan Statistik}

Analisis kimia berupa proksimat pakan uji, ikan awal, dan ikan akhir yang meliputi protein kasar (semimikro Kjeldahl), lemak kasar (ekstraksi eter), kadar air (pemanasan suhu $110^{\circ} \mathrm{C}$ selama $24 \mathrm{jam}$ ), kadar abu (pengabuan dengan muffle-furnance pada suhu $550^{\circ} \mathrm{C}$ selama 24 jam), dan serat kasar (fibretex). Analisis komposisi asam amino total terhadap tepung ikan dan tepung darah dan asam amino bebas terhadap tepung darah dilakukan di Laboratorium Dasar Bersama, Universitas Airlangga, Surabaya, menggunakan metode HPLC khusus deteksi Ninhydrin postcolumnreaction dengan alat high speed amino acid analyzer-Hitachi model 835 dan hasilnya disajikan pada Tabel 2 dan 3. Analisis kadar kromium oksida dalam pakan dan feses dilakukan dengan menggunakan spektrofotometer pada panjang gelombang $350 \mathrm{~nm}$ (Watanabe, 1988).

Data parameter pertambahan bobot, laju pertumbuhan spesifik, efisiensi pakan, rasio efisiensi protein, retensi protein, dan sintasan ikan dianalisis ragam, jika terdapat perbedaan yang nyata dilanjutkan dengan uji Tukey (Steel \& Torrie, 1995). Sedangkan nilai kecernaan pakan dianalisis secara deskriptif. Selain itu, dilakukan pengamatan kualitas air seperti suhu, salinitas, $\mathrm{pH}$, oksigen terlarut, nitrat, nitrit, fosfat, serta kecerahan selama penelitian. Nilai kualitas air ini cukup layak bagi pertumbuhan ikan kerapu macan (Tabel 4). 
Tabel 2. Komposisi asam amino esensial dalam tepung ikan, tepung darah tanpa perlakuan (TB), tepung darah + ekstrak enzim protease (TC), dan tepung darah + mikroba Flavo cytophaga (TD) (\%b/b)

Table 2. Essential amino acid composition of fish meal, blood meal without treatment, blood meal + crude protease enzyme and blood meal + microbes Flavo cytophaga $(\% \mathrm{w} / \mathrm{w})$

\begin{tabular}{lcccc}
\hline \multirow{2}{*}{$\begin{array}{c}\text { Jemino asam } \\
\text { Essential a mino }\end{array}$} & \multirow{2}{*}{$\begin{array}{c}\text { Tepung ikan } \\
\text { Fish meal }\end{array}$} & \multicolumn{2}{c}{ Tepung darah (Blood meal ) } \\
\cline { 3 - 5 } & 3.33 & 3.72 & 4.23 & 3.75 \\
\hline Threonine & 3.10 & 5.12 & 5.38 & 5.10 \\
Valine & 2.13 & 0.33 & 0.12 & ttd \\
Methionine & 2.63 & 0.51 & 0.79 & 0.70 \\
Isoleucine & 5.43 & 8.89 & 9.86 & 10.15 \\
Leucine & 3.18 & 5.54 & 6.04 & 5.57 \\
Phenylalanine & 5.74 & 6.50 & 6.96 & 6.45 \\
Lysine & 2.40 & 5.01 & 5.57 & 5.15 \\
Histidine & 4.20 & 2.60 & 3.05 & 3.13 \\
Arginine & $\mathrm{ttd}$ & $\mathrm{ttd}$ & $\mathrm{ttd}$ & $\mathrm{ttd}$ \\
Tryptophan & &
\end{tabular}

Keterangan (Note): $\mathrm{ttd}=$ tidak terdeteksi (not detected)

Tabel 3. Komposisi asam amino (esensial) bebas pada tepung darah tanpa perlakuan (TB), tepung darah + ekstrak enzim protease (TC), dan tepung darah + mikroba Flavo cytophaga (TD) (\%b/ b)

Table 3. Free amino acid (essensial) composition of blood meal without tr eatment (TB), blood meal + crude protease enzyme (TC) and blood meal + microbes Flavo cytophaga (TD) $(\% \mathrm{w} / \mathrm{w})$

\begin{tabular}{lccc}
\hline \multirow{2}{*}{$\begin{array}{l}\text { Jenis asam amino } \\
\text { Amino acid com position }\end{array}$} & \multicolumn{3}{c}{ Tepung darah (Blood meal) } \\
\cline { 2 - 4 } & TB & TC & TD \\
\hline Threonine & - & - & - \\
Valine & - & - & 0.115 \\
Methionine & 0.008 & - & - \\
Isoleucine & - & - & 0.069 \\
Leucine & - & 0.079 & 0.077 \\
Phenylalanine & - & 0.086 & - \\
Lysine & 0.047 & 0.052 & 0.064 \\
Histidine & - & - & - \\
Arginine & - & - & 0.097 \\
\hline
\end{tabular}

\section{HASIL DAN BAHASAN}

Kandungan asam amino esensial tepung darah yang diberi perlakuan baik dengan ekstrak kasar enzim protease maupun fermentasi dengan mikroba Flavo cytophaga (penghasil enzim protease) sedikit meningkatkan konsentrasinya (Tabel 2) seperti asam amino threonine, isoleucine, leucine, dan arginine. Mekanisme peningkatan kandungan asam amino ini belum jelas. Tepung darah mengandung beberapa asam amino esensial 
Tabel 4. Kualitas air di keramba jaring apung selama 20 minggu pemeliharaan ikan kerapu macan

Table 4. Water quality in cage during rearing period of tiger grouper

\begin{tabular}{lc}
\hline \multicolumn{1}{c}{$\begin{array}{c}\text { Parameter } \\
\text { Parameters }\end{array}$} & $\begin{array}{c}\text { Kisaran } \\
\text { Revolve }\end{array}$ \\
\hline Suhu (Temperature) $\left({ }^{\circ} \mathrm{C}\right)$ & $26.88-30.12$ \\
Salinitas (Salinity) $(\mathrm{ppt})$ & $32.05-33.67$ \\
$\mathrm{pH}$ & $7.57-8.70$ \\
$\mathrm{Oksigen} \mathrm{terlarut}$ & $4.29-6.81$ \\
Dissolved oxygen (mg/ L) & \\
$\mathrm{NO}_{3}(\mathrm{mg} / \mathrm{L})$ & $0.0088-1.0086$ \\
$\mathrm{NO}_{2}(\mathrm{mg} / \mathrm{L})$ & $0.0001-0.9133$ \\
$\mathrm{PO}_{4}(\mathrm{mg} / \mathrm{L})$ & $0.0001-0.6406$ \\
$\mathrm{Kecerahan}$ (Turbidity ) (m) & $6.0-10.20$ \\
\hline
\end{tabular}

yang kadarnya rendah seperti methionine, isoleucine, dan tryptophan. Oleh karena itu, penggunaan tepung darah dalam pakan ikan juga dibatasi oleh faktor ini dan dapat dikomplementer dengan sumber protein lainnya yang mengandung cukup banyak asam amino tersebut seperti tepung ikan. Sementara asam amino (essensial) bebas (Tabel 3) yang terukur juga sedikit mengalami peningkatan dengan adanya perlakuan tersebut, meskipun nilainya relatif kecil. Silalahi \& Hutagalung (2013) mengemukakan bahwa asam amino bebas dalam proses pengolahan berubah menjadi senyawa amin. Sebagian senyawa amin aktif secara fisiologis. Amin bioaktif ini terdapat sedikit di dalam bahan makanan dan biasanya tidak beracun tetapi di dalam makanan yang diolah dengan proses fermentasi akan meningkatkan beberapa amin bioaktif sehing ga dapat bersifat toksis.

Hal yang penting dalam penilaian kualitas tepung darah ini adalah koefisien kecernaan pakan. Salah satu variabel yang menentukan kualitas pakan ikan budidaya adalah mengetahui koefisien kecernaan pakan. Semakin tinggi koefisien kecernaan pakan, maka cenderung semakin baik pakan tersebut. Pada Tabel 5 terlihat bahwa nilai koefisien kecernaan bahan kering dan protein pakan yang mengandung tepung darah yang diberi perlakuan relatif mengalami peningkatan dibandingkan dengan koefisien kecernaan pakan uji yang mengandung tepung darah tanpa perlakuan. Hal ini menunjukkan bahwa tepung darah yang diberi perlakuan ekstrak kasar enzim protease maupun dengan mikroba Flavo cytophaga penghasil enzim protease tersebut mampu meningkatkan ketersediaan biologi tepung darah. Hal ini sejalan dengan penemuan Laining et al. (2003b) bahwa tingkat kecernaan bahan kering dan protein tepung darah yang tidak difermentasi masing- masing sebesar 48,1\%dan 55,2\%lebih kecil daripada tepung darah yang disilase yang memiliki tingkat kecernaan berturut- turut $67,9 \%$ dan $61,7 \%$ untuk bahan kering dan $87,5 \%$ dan $84,2 \%$ untuk protein. Menurut Hertrampf \& PiedadPascual (2000), tingkat kecernaan tepung

Tabel 5. Koefisien kecernaan pakan kontrol (A), tepung darah tanpa perlakuan (B), tepung darah yang diberi enzim protease (C) dan tepung darah yang diberi mikroba Flavo cytophaga (D) (\%)

Tabel 5. Apparent digestibility coefficient (ADC) of the control diet (A), blood meal without (B), blood meal with protease enzyme (C), and blood meal with microbes Flavo cytophaga (D) (\%)

\begin{tabular}{lcccc}
\hline \multicolumn{1}{c}{$\begin{array}{l}\text { Parameter } \\
\text { Parameters }\end{array}$} & \multicolumn{4}{c}{ Pakan percobaan (Diets test) } \\
\cline { 2 - 5 } & A & B & C & D \\
\hline $\begin{array}{l}\text { Koefisien kecernaan bahan kering } \\
\text { ADC of dry matter }\end{array}$ & 50.95 & 42.77 & 51.16 & 50.60 \\
$\begin{array}{l}\text { Koefisien kecernaan protein } \\
\text { ADC of protein } \\
\begin{array}{l}\text { Koefisien kecernaan lemak } \\
\text { ADC of lipid }\end{array}\end{array}$ & 77.73 & 71.78 & 78.53 & 78.45 \\
\hline
\end{tabular}


darah sangat tergantung pada penanganan tepung darah sebelum digunakan dalam pakan formulasi.

Pemberian pakan untuk semua perlakuan memberikan pertambahan bobot pada ikan kerapu macan (Gambar 1). Hal ini menunjukkan bahwa pakan yang diberikan mampu digunakan oleh ikan uji untuk pertumbuhannya, melebihi kebutuhan untuk metabolisme dasarnya. Namun pada minggu ke- 12 , mulai terlihat adanya perbedaan pertumbuhan sebagai akibat adanya perbedaan perlakuan, di mana ikan yang diberi pakan tidak mengandung tepung darah (pakan kontrol) cenderung memiliki pertumbuhan yang tertinggi, diikuti berturut- turut oleh ikan yang diberi pakan tepung darah yang ditambahkan ekstrak kasar enzim protease (perlakuan C), ikan yang diberi pakan tepung darah yang ditambahkan mikroba Flavo cytophaga (pelakuan D), dan terakhir ikan yang diberi pakan tepung darah tanpa perlakuan (perlakuan B).

Menurut Hasan (2000), kehadiran enzim dalam pakan buatan dapat membantu dan mempercepat proses pencernaan sehingga nutrien dapat cukup tersedia untuk pertumbuhan dan sintasan ikan. Semakin banyak enzim yang ditambahkan ke dalam pakan, maka akan menghasilkan lebih banyak protein yang dihidrolisis menjadi asam amino, sehingga akan meningkatkan daya cerna ikan terhadap pakan. Penambahan enzim protease ke dalam pakan ikan mampu meningkatkan hidrolisis protein pakan yang berakibat pada tingkat kecernaan pakan yang semakin meningkat. Tingginya tingkat kecernaan pakan dapat meningkatkan tingkat penyerapan asam amino ke dalam tubuh untuk pertumbuhan (Amali et al., 2013).

Setelah pemeliharaan ikan selama 20 minggu, ikan yang diberi pakan mengandung 18\%tepung darah tanpa perlakuan memiliki pertambahan bobot, laju pertumbuhan spesifik dan rasio efisiensi protein yang lebih rendah dan berbeda nyata $(P<0,05)$ dibandingkan dengan ikan yang diberi pakan yang tidak mengandung tepung darah (Tabel 6). Sementara ikan yang diberi pakan mengandung $18 \%$ tepung darah yang diberi ekstrak kasar enzim protease (perlakuan C) maupun dengan mikroba Flavo cytophaga (perlakuan D) memiliki pertambahan bobot, laju pertumbuhan spesifik, dan rasio efisiensi protein yang tidak berbeda nyata $(P>0,05)$ dengan ikan yang diberi pakan kontrol (A), meskipun ikan yang diberi pakan $C$ dan $D$ juga memiliki pertambahan bobot, laju pertumbuhan spesifik dan rasio efisiensi protein yang relatif sama $(P>0,05)$ dengan ikan yang diberi pakan B. Hal

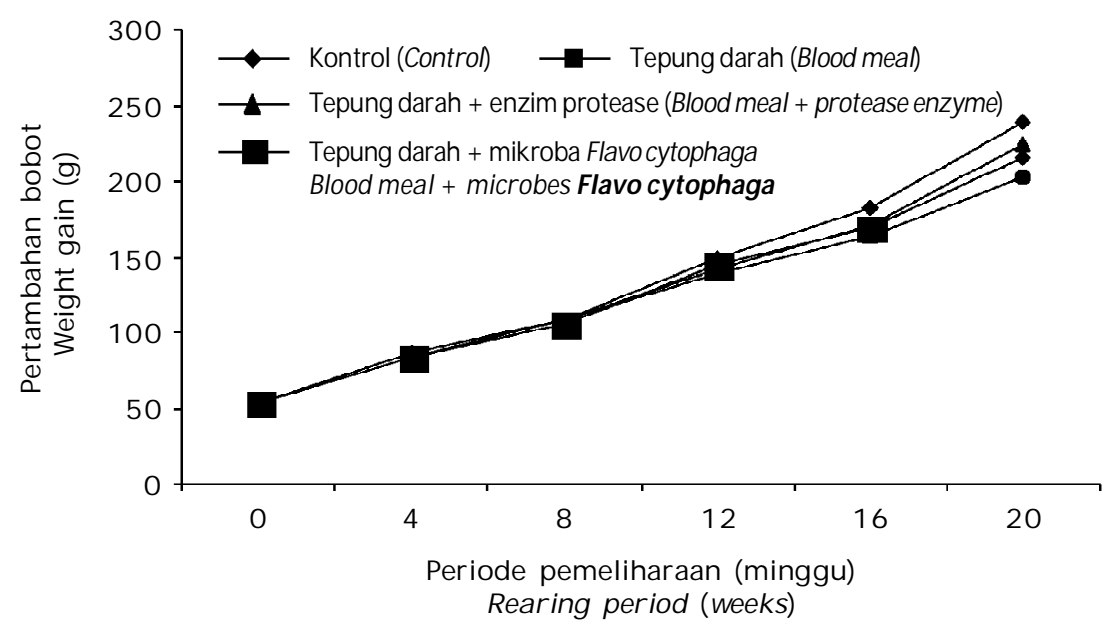

Gambar 1. Pola pertumbuhan bobot ikan kerapu macan yang diberi pakan kontrol, tepung darah, tepung darah yang diberi enzim protease, dan tepung darah yang diberi mikroba Flavo cytophaga selama 20 minggu pemeliharaan

Figure 1. Weight growth pattern tiger grouper fed controls, blood meal, blood meal with protease enzyme, and blood meal with microbes Flavo cytophaga during 20 weeks of maintenance 
Tabel 6. Rata- rata pertumbuhan, retensi protein, efisiensi pakan, dan rasio efisiensi protein ikan kerapu macan yang diberi pakan kontrol (A), tepung darah (B), tepung darah yang diberi enzim protease (C), dan tepung darah yang diberi mikroba Flavo cytophaga (D) selama 20 minggu pemeliharaan

Table6. The aver age of growth, protein retention, feed efficiency, and protein efficiency ratio tiger grouper fed the control diet (A), blood meal (B), blood meal with protease enzyme (C), and blood meal with microbes Flavo cytophaga (D) during 20 weeks of maintenance

\begin{tabular}{lcccc}
\hline \multicolumn{1}{c}{ Parameter } & \multicolumn{3}{c}{ Pakan percobaan (Diets test ) } \\
\cline { 2 - 5 } & A & B & C & D \\
\hline $\begin{array}{l}\text { Pertambahan bobot } \\
\text { Weight gain (g) }\end{array}$ & $184.36 \pm 8.59^{\mathrm{a}}$ & $148.96 \pm 19.42^{\mathrm{b}}$ & $171.20 \pm 7.57^{\mathrm{ab}}$ & $161.59 \pm 9.46^{\mathrm{ab}}$ \\
$\begin{array}{l}\text { Laju pertumbuhan spesifik (\% hari) } \\
\text { Specific growth rate (\% day) }\end{array}$ & $1.06 \pm 0.03^{\mathrm{a}}$ & $0.94 \pm 0.07^{\mathrm{b}}$ & $1.02 \pm 0.02^{\mathrm{ab}}$ & $0.99 \pm 0.04^{\mathrm{ab}}$ \\
$\begin{array}{l}\text { Rasio efisiensi protein } \\
\text { Protein efficiency ratio }\end{array}$ & $1.25 \pm 0.06^{\mathrm{a}}$ & $1.08 \pm 0.11^{\mathrm{b}}$ & $1.18 \pm 0.03^{\mathrm{ab}}$ & $1.09 \pm 0.05^{\mathrm{ab}}$ \\
$\begin{array}{l}\text { Efisiensi pakan } \\
\text { Feed efficiency (\%) }\end{array}$ & $0.69 \pm 0.03^{\mathrm{a}}$ & $0.61 \pm 0.06^{\mathrm{a}}$ & $0.68 \pm 0.02^{\mathrm{a}}$ & $0.62 \pm 0.03^{\mathrm{a}}$ \\
$\begin{array}{l}\text { Retensi protein } \\
\text { Protein retention (\% }\end{array}$ & $22.47 \pm 1.06^{\mathrm{a}}$ & $19.95 \pm 2.09^{\mathrm{a}}$ & $21.49 \pm 0.59^{\mathrm{a}}$ & $19.53 \pm 0.89^{\mathrm{a}}$ \\
$\begin{array}{l}\text { Sintasan } \\
\text { Survival rate }(\%)\end{array}$ & $95.00^{\mathrm{a}}$ & $86.67 \pm 11.55^{\mathrm{a}}$ & $91.67 \pm 5.77^{\mathrm{a}}$ & $96.67 \pm 2.89^{\mathrm{a}}$ \\
\hline
\end{tabular}

Angka rata- rata dalam baris dengan notasi huruf yang berbeda menunjukkan perbedaan yang nyata Mean values in rows with different notation indicate statistically significant differ ence $(P<0,05)$

ini menunjukkan bahwa pakan $\mathrm{C}$ dan pakan $\mathrm{D}$ memiliki kualitas yang relatif sama dengan pakan A.

Tepung darah tanpa perlakuan memiliki koefisien kecernaan yang rendah sehingga berakibat pada pertumbuhan ikan yang rendah pula. Peningkatan kualitas tepung darah yang diberi perlakuan ini diakibatkan adanya ekstrak kasar enzim protease yang diproduksi dari Flavo cytophaga. Enzim protease ini dapat menghidrolisis ikatan peptida yang kompleks dalam protein tepung darah menjadi molekul yang lebih sederhana seperti dipeptida ataupun menjadi asam amino bebas. Senyawa penyusun protein yang lebih sederhana dalam pakan akan mudah dicerna oleh ikan sehingga tingkat penyerapannya menjadi tinggi dan sedikit yang terbuang dalam bentuk padatan atau feses. Hal ini tentunya akan meningkatkan peluang pemanfaatan protein pakan untuk disintesis menjadi protein tubuh ikan. Pemberian bahan pakan yang sudah difermentasi dapat menyebabkan perubahan sifat bahan pakan karena adanya reaksi oksidasi- reduksi di dalam sistem biologi dan menghasilkan energi (Winarno et al., 1980; Winarno, 1986). Pada proses fermentasi padat, dihasilkan berbagai enzim ekstraselular yang dapat menghidrolisis polimer substrat fermentasi menjadi nutrien yang dapat dimanfaatkan (Suhartono, 1989).

Beberapa bakteri flora saluran pencernaan ikan juga telah dilaporkan memiliki potensi yang besar untuk meningkatkan efisiensi pemanfaatan pakan karena mampu menghasilkan enzim ekstraseluler yang akan membantu ikan untuk mencerna komponen pakan yang lebih kompleks (De Schrijver \& Ollevier, 2000; Bairagi et al., 2002; El- Haroun et al., 2006). Pada penelitian ini terlihat bahwa pemberian tepung darah yang diberi perlakuan dapat meningkatkan pertambahan bobot ikan kerapu macan dibandingkan dengan pemberian tepung darah tanpa diberi perlakuan. Hal ini disebabkan karena adanya peran bakteri Flavo cytophaga yang menghasilkan enzim protease ekstraseluler yang dapat membantu mencerna komponen protein 
pakan yang lebih kompleks menjadi lebih sederhana, sehingga meningkatkan ketersediaan biologi tepung darah sebagai komponen pakan ikan kerapu macan. De Schrijver \& Ollevier (2000) juga melaporkan bahwa penambahan Vibrio proteolyticus (probiotik penghasil enzim proteolitik) ke dalam pakan ikan yuwana ikan turbot (Scaphthalmus maximus) ternyata mampu menurunkan bobot molekul fraksi protein (ikatan peptida lebih sederhana) digesta dalam lambung dan usus ikan, sehingga tingkat kecernaan protein pakan menjadi meningkat dibandingkan pakan yang tidak ditambahkan probiotik tersebut. Aslamyah (2006) menemukan bahwa bakteri Carnobacterium sp. yang diisolasi dari usus ikan bandeng mampu memproduksi enzim ekstraseluler seperti amylase, protease, dan lipase, sehingga sangat membantu pencernaan pakan ikan ketika bakteri atau enzim yang dihasilkannya tersebut dimasukkan ke dalam pakan. Hasan (2000) melaporkan bahwa enzim yang berasal dari usus ikan gurame dewasa mampu menghidrolisis protein dalam pakan ikan gurame.

Efisiensi pakan untuk semua perlakuan memberikan nilai yang tidak berbeda nyata $(P>0,05)$. Efisiensi pakan adalah rasio antara pertambahan bobot dengan jumlah pakan yang diberikan selama penelitian. Nilai efisiensi pakan yang tinggi menunjukkan penggunaan pakan yang efisien sehingga dengan sedikit pakan saja sudah dapat diuraikan untuk memenuhi kebutuhan energi dan selebihnya digunakan untuk pertumbuhan. Nilai efisiensi pakan yang diperoleh pada penelitian ini hampir sama dengan nilai efisiensi pakan ikan kerapu macan yang diberi pakan mengandung $15 \%$ tepung darah campuran asam propionat dan asam formiat (1:1) yaitu sebesar $0,68 \%$ (Usman et al., 2006).

Pertambahan kadar protein dalam tubuh ikan uji setelah pemberian pakan selama 20 minggu yang dinyatakan dalam retensi protein memberikan nilai yang tidak berbeda nyata $(P>0,05)$ pada semua perlakuan. Hal ini ditunjang dengan hasil analisis protein dalam tubuh ikan kerapu macan pada akhir penelitian (Tabel 7), di mana diperoleh kadar protein (bobot kering) dalam tubuh ikan memberikan nilai yang hampir sama untuk semua perlakuan. Retensi protein menggambarkan banyaknya protein makanan yang disimpan menjadi protein tubuh dibandingkan dengan jumlah protein dalam makanan yang dikonsumsi. Hal ini menunjukkan bahwa, meskipun kecernaan protein pakan yang relatif lebih tinggi pada ikan yang diberi pakan $A, C$, dan D dibandingkan pada ikan yang diberi pakan $B$, dan berimplikasi pada adanya peningkatan pertumbuhan yang juga relatif tinggi pada ikan yang diberi pakan $A, C$, dan D, namun jumlah protein yang tersimpan dalam tubuh ikan masih memiliki proporsi yang relatif sama terhadap jumlah protein pakan yang dikonsumsi oleh ikan pada semua perlakuan. Kondisi retensi protein pakan dipengaruhi oleh banyak faktor antara lain kualitas protein pakan, imbangan rasio protein dan energi pakan, jenis dan ukuran ikan, serta kondisi lingkungan budidaya (Mambrini \& Guillaume, 1999), karena ikan banyak menggunakan protein sebagai sumber energi (Furuichi, 1988; Wilson, 2002), khususnya ikan karnivora seperti kerapu macan.

Tabel 7. Kandungan nutrisi ikan kerapu macan yang diberi pakan kontrol (A), tepung darah (B), tepung darah yang diberi enzim protease (C), dan tepung darah yang diberi mikroba Flavo cytophaga (D) pada akhir penelitian (\%bobot kering)

Table 7. Nutrient content of tiger grouper fed control (A), blood meal (B), blood meal with protease enzyme (C), and blood meal with microbes Flavo cytophaga (D) at the end of trial (\% dry weight)

\begin{tabular}{lcccc}
\hline \multirow{2}{*}{$\begin{array}{c}\text { Komposisi } \\
\text { Composition }\end{array}$} & \multicolumn{4}{c}{ Ikan akhir (Final fish) } \\
\cline { 2 - 5 } & A & B & C & D \\
\hline Protein kasar (Crude protein) & 57.10 & 57.18 & 57.67 & 57.06 \\
Lemak kasar (Crude lipid) & 18.19 & 19.15 & 19.56 & 19.68 \\
Abu (Ash) & 20.65 & 20.28 & 20.04 & 19.59 \\
Serat kasar (Crude fiber) & 2.12 & 2.34 & 2.14 & 1.59 \\
\hline
\end{tabular}




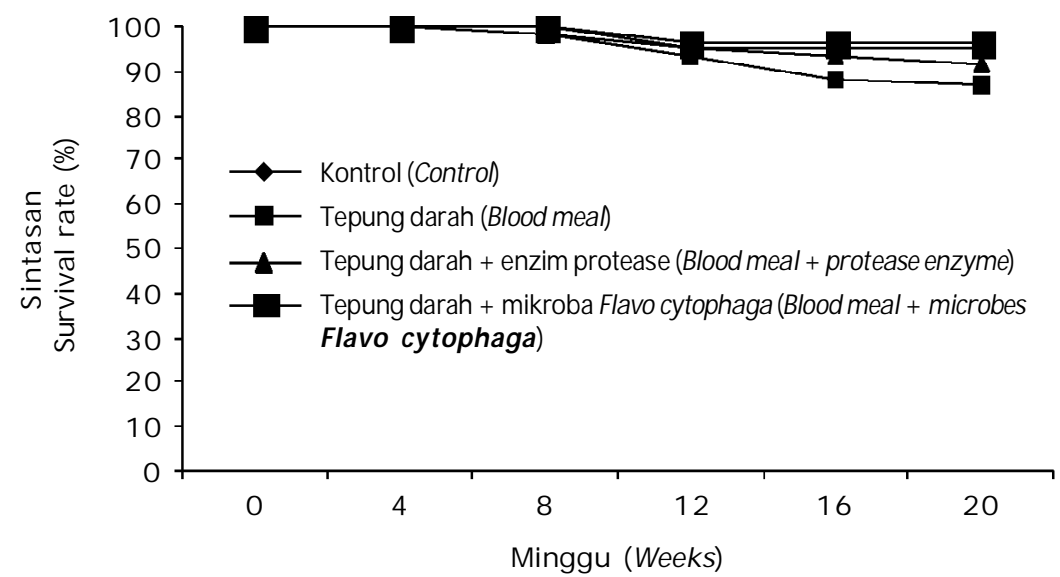

Gambar 2. Sintasan (\% ikan kerapu bebek selama 20 minggu pemeliharaan

Figure 2. Survival rate (\%) of humpback grouper after 20 weeks culture

Nilai sintasan ikan yang diperoleh pada semua perlakuan masih relatif sama $(P>0,05)$ hingga pemeliharaan 20 minggu (Tabel 6). Namun demikian, ikan yang diberi pakan mengandung tepung darah tanpa perlakuan cenderung mengalami kematian yang relatif lebih tinggi dibandingkan perlakuan lainnya. Kematian ikan selama periode penelitian (Gambar 2) menunjukkan bahwa ikan yang diberi pakan mengandung tepung darah tanpa perlakuan mengalami kematian lebih awal (minggu 4) daripada perlakuan lainnya dan terus mengalami kematian, sehingga bisa dipastikan bahwa seandainya penelitian ini terus dilanjutkan, maka kemungkinan besar tingkat mortalitas ikan ini akan berbeda nyata dengan perlakuan Iainnya. Kematian yang terjadi pada perlakuan Bini sebagai akibat dari tubuh ikan kerapu macan yang kena borok dan mata membengkak. Hal ini diduga disebabkan oleh kualitas salah satu bahan pakan yang rendah seperti tepung darah yang tidak melalui fermentasi, karena keadaan ini tidak dijumpai pada perlakuan lain. Pada ikan Chinook salmon (Oncorhynchus tschawynchus) substitusi tepung ikan dengan tepung darah sebanyak 7,5\% memberikan efek patologi yang kurang baik (Hajen et al., 1993).

\section{KESIMPULAN}

Dari hasil penelitian ini dapat disimpulkan bahwa tepung darah yang ditambahkan ekstrak kasar enzim protease yang diproduksi dari mikroba Flavo cytophaga dan dengan penambahan mikroba Flavo cytophaga dapat mening- katkan pertumbuhan, rasio efisiensi protein, efisiensi pakan, sintasan, dan koefisien kecernaan pakan ikan kerapu macan dibanding dengan tepung darah tanpa fermentasi.

Kualitas pakan yang dihasilkan dari perlakuan tepung darah yang ditambahkan ekstrak kasar enzim protease dan dengan penambahan mikroba Flavo cytophaga tidak berbeda dengan kualitas pakan menggunakan tepung ikan 100\%sebagai sumber utama protein dilihat dari aspek pertumbuhan, rasio efisiensi protein, efisiensi pakan, retensi protein, dan koefisien kecernaan pakan.

\section{UCAPAN TERIMA KASIH}

Ucapan terima kasih Penulis sampaikan kepada Reni Yulianingsih, Rosni, Tamsil, Yohanes Teken, Umar, dan Ramadhan atas bantuannya sehingga riset ini dapat berjalan dengan baik.

\section{DAFTAR ACUAN}

Amali, R., Subandiyono, dan Arini, E. 2013. Pengaruh penggunaan papain terhadap tingkat pemanfaatan protein pakan dan pertumbuhan lele dumbo (Clarias gariepinus). Journal of Aquaculture Management and Technology, 2(1): 136- 143.

Aslamyah, S. 2006. Penggunaan mikroflora saluran pencernaan sebagai probiotik untuk meningkatkan pertumbuhan dan kelangsungan hidup ikan bandeng. Disertasi. Sekolah Pascasarjana, Institut Pertanian Bogor. Bogor, $103 \mathrm{hlm}$. 
Bairagi, A., Ghosh, K.S., Sen, S.K., \& Ray, A.K. 2002. Enzyme producing bacterial flora isolated from fish digestive tracts. Aquaculture Internatioal, 10: 109-121.

De Schrijver, R. \& Ollevier, F. 2000. Protein digestion in juvenile turbot (Scophthalmus maximus) and effect of dietary administration of Vibrio proteolyticus. Aquaculture, 186: 107-116.

El- Haroun, E.R., Gado, A.S., Kabir, A.M., \& Chowdhurry, M.A. 2006. Effect of dietary probiotic Biogen supplementation as a growth promotor on growth performance and feed utilization of nile tilapia Oreochromis niloticus (L.). Aquaculture Research, 37: 1,473-1,480.

Fujaya, Y. 2004. Fisiologi Ikan. Dasar Pengembangan dan Teknik Perikanan. Rineka Cipta. Jakarta, $179 \mathrm{hlm}$

Furuichi, M. 1988. Carbohydrate. Dalam Watanabe, T. (Ed.) Fish Nutrition and Mariculture. Department of Aquatic Biosciences, University of Fisheries. Tokyo, p. 44- 55.

Hajen, W.E., Beames, R.M., Higgs, D.A., \& Dosanjh, B.S. 1993. Digestibility of various feedstuffs by post-juvenile Chinook salmon (Oncorhyncus tshawytscha) in sea water, 2. Measurement of digestibility. Aquaculture, 112(4): 333- 348.

Hardy, R.W. 1989. Diet preparation, In Halver, J.E. (Ed.). Fish Nutrition. Second Edition. Academic Press, Inc. San Diego, p. 475- 548.

Hasan, O.D.S. 2000. Pengaruh pemberian enzim papain dalam pakan buatan terhadap pemanfaatan protein dan pertumbuhan benih ikan gurame (Osphronemus gouramy Lac.). Tesis. Program Pascasarjana Institut Pertanian Bogor. Bogor, $57 \mathrm{hlm}$.

Hertrampf, J.W. \& Piedad- Pascual, P. 2000. Handbook on ingredient for aquaculture feeds. Kluwer Academic Publishers. 573 pp.

Kabangnga, N., Burhanuddin, Usman, Lante, S., \& Kamaruddin. 2004. Kebutuhan optimum protein dan energi pakan pembesaran ikan kerapu macan di tambak. Laporan Hasil Penelitian. Balai Riset Perikanan Budidaya Air Payau, Maros, $6 \mathrm{hlm}$.

Laining, A., Kabangnga, N., \& Usman. 2003a. Pengaruh protein pakan yang berbeda terhadap koefisien kecernaan nutrien serta performansi biologis kerapu macan, Epinephelus fuscoguttatus, dalam keramba jaring apung. Jurnal Penelitian Perikanan Indonesia, 9(2): 29- 34.
Laining, A., Rachmansyah, Ahmad, T., \&Williams, K., 2003b. Apparent digestibility of selected feed ingredients for humpback grouper, Cromileptes altivelis. Aquaculture, 218: 529- 538.

Mambrini, M. \& Guillaume, J. 1999. Protein nutrition. In Guillaume, J., Kaushik, S., Bergot, P., $\&$ Metailler, R. (Eds.) Nutrition and feeding of fish and crustaceans. INRA, IFREMER, UK. P. 81- 109.

Palinggi, N.N. 2008. Pengaruh penambahan Aspergillus niger dalam tepung darah terhadap kecernaan pakan ikan kerapu bebek, Cromileptes altivelis. Prosiding Seminar Nasional Perikanan dan Kelautan. Universitas Brawijaya. Malang, $4 \mathrm{hlm}$.

Rachmansyah, Laining, A., \& Yulianingsih, R. 1999. Nilai nutrisi tepung darah hasil fermentasi dan kemungkinan pemanfaatannya sebagai sumber protein pakan ikan. Laporan Hasil Penelitian. Balai Penelitian Perikanan Pantai. Maros, $11 \mathrm{hlm}$.

Rao, M.B., Tanksale, A.M., Ghatge, M.S., \& Deshpande, V.V. 1998. Molecular and Biotechnological Aspects of Microbial Proteases. Microbiol. Mol. Biol. Rev., 62(3): 597635.

Schulz, C., Knaus, U., Wirth, M., \& Rennert, B. 2005. Effect of varying dietary fatty acid propile on growth performance, fatty acid, body and tissue composition of juvenile pike perch (Sander lucioperca). Aquaculture Nutrition, 11: 403-413.

Silalahi, J. \&Hutagalung, N. 2013. Komponenkomponen bioaktif dalam makanan dan pengaruhnya terhadap kesehatan. File:// /D:/ pus- 3.htm.

Steel, R.G.D. \& Torrie. J.H. 1995. Prinsip dan prosedur statistika. Alih bahasa: Bambang Sumantri. Gramedia Pusaka Utama. Jakarta, $748 \mathrm{hlm}$.

Suhartono, M.T. 1989. Enzim dan bioteknologi. Departemen Pendidikan dan Kebudayaan. Dirjen Pendidikan Tinggi, Antar Universitas Bioteknologi, Institut Pertanian Bogor. 322 hlm.

Takeuchi, T. 1988. Laboratory work- chemical evaluation of dietary nutrient. In Watanabe, $\mathrm{T}$ (Ed.) Fish nutrition and mariculture. JICA Kanagawa International Fisheries Training Centre. Tokyo, p. 179- 233.

Usman, Palinggi, N.N., Rachmansyah, Kamaruddin, \&Ahmad, T. 2006. Fermented blood meal use for tiger grouper, Epinephelus fuscoguttatus grow out diet. 
Laporan Hasil Penelitian. Balai Riset Perikanan Budidaya Air Payau. Maros, $10 \mathrm{hlm}$.

Watanabe, T. 1988. Fish nutrition and mariculture. JICA Textbook. The General Aquaculture Course. Kanagawa International Fisheries Training Centre. Japan International Cooperation Agency (JICA). 233 pp.

Wilson, R.P. 2002. Amino acids and proteins. Dalam Halver, J.E. \&Hardy, R.W., (Eds.). New York: Academic Press. Fish Nutrition, p. 143179.

Winarno, F.G., Fardiaz, S., \& Fardiaz, D. 1980. Pengantar teknologi pangan. Gramedia. Jakarta, $92 \mathrm{hlm}$.
Winarno, F.G. 1986. Kimia pangan dan gizi. Gramedia. Jakarta, $232 \mathrm{hlm}$.

Yamin, M., Palinggi, N.N., \&Rachman Syah. 2005. Pengaruh logam $\mathrm{FeCl}_{3}$ terhadap aktivitas enzim protease ikan kerapu macan. Laporan Hasil Penelitian. Balai Riset Perikanan Budidaya Air Payau. Maros, $7 \mathrm{hlm}$.

Yamin, M., Palinggi, N.N., \&Rachman Syah. 2008. Aktivitas enzim protease dalam lambung dan usus ikan kerapu macan setelah pemberian pakan. Media akuakultur, 3(1): 40- 44 . 